Karl Heinz Roth und Elisabeth Behrens, Die »andere « Arbeiterbewegung und die Entwicklung der kapitalistischen Repression von 1880 bis zur Gegenwart. Ein Betrag zum Neuverständnis der Klassengeschichte in Deutschland. Mit ausführlicher Dokumentation zur Aufstandsbekämpfung, Werkschutz u.a. Trikont Verlag, München 1974, 395 s., kr. 54,85.

\title{
Paul Mattick
}

Som udtryk for kapitalistiske produktionsforhold er arbejderbevægelsen samtidig en bevægelse af arbejdere, der må udvikle deres klassebevidsthed inden for de kapitalistiske markedsforhold. Den almene konkurrence indbefatter arbejdernes indbyrdes konkurrence. Selv om de mange kapitaler danner totalkapitalen optræder kapitalen ikke som totalkapitalist, og selv om alle arbejdere udfører totalarbejde findes der ingen totalarbejder. Men hvad der end måtte være resultatet af kapitalkonkurrencen og konkurrencen om arbejdspladserne - reproduktionen af det kapitalistiske samfund er og bliver reproduktion af kapitalistiske produktions- eller klasseforhold, hvorpå markedsforholdene beror.

Den af kapitalakkumulationen bestemte kapitalistiske arbejdsdeling giver ikke blot de forskellige kapitaler, men også forskellige grupper af arbejdere lejlighed til at sætte specielle interesser igennem inden for de givne klasseforhold. Således er arbejderbevægelsen ganske vist en bevægelse, der beror på klassemodsætninger, men samtidig en bevægelse, der ved siden af klasseinteressen også repræsenterer særlige faglige interesser. Den almene proletariske interesse, der eksisterer inden for rammerne af det kapitalistiske samfund, blev af Marx betegnet som »politisk økonomi - men fra arbejdernes standpunkt «, nemlig som vedvarende kamp mod den kapitalistiske merværdifrembringelse. Ligesom bourgeoisiets er også arbejdernes politiske økonomi bundet til kapitalens eksistens. Det drejer sig her endnu om en mere eller mindre $h ø j$ udbytningsgrad, ikke om udbytningen selv. Man ville derfor kun kunne forestille sig klassebevidsthedens og arbejderbevægelsens udvikling som en revolutionær proces, der med lønarbejdet til sidst ville overvinde samfundets klassespaltning.

Denne forventning er dog indtil nu ikke blevet indfriet. Varetagelsen af direkte specielle interesser inden for de kapitalistiske produktionsforhold fremstod for arbejderne som langt vigtigere end disses 
revolutionære overvindelse, der kun lod sig henføre til en usikker fremtid. Den klassebevidsthed, der udvikledes, blev ikke til revolutionær klassebevidsthed. De i denne forbindelse uopfyldte forventninger krævede en forklaring. De måtte især have ramt Friedrich Engels, forfatteren af bogen »Die Lage der arbeitenden Klasse in England «. Den af ham beskrevne elendiggjorte arbejderklasse, til hvem man kunne knytte revolutionære forhåbninger, var i $1 \varnothing$ bet af få årtier blevet til en arbejderklasse, der afviste enhver revolutionær bevægelse, der følte sig hjemme inden for de givne forhold. Den forklaring, som Engels fandt, var ikke, som man egentlig kunne forvente, den tiltagende produktivitet og dermed udbytning af de engelske arbejdere, der tillod en samtidig forhøjelse af lønninger og profitter, men derimod korrumperingen af arbejderne gennem deres villige deltagelse i den imperialistiske udbytning af verden, der blev praktiseret af den engelske kapital. Denne ide blev senere taget op af Lenin for at give udtryk for hans egen skuffelse over arbejdernes adfærd. Den imperialistiske kapitalisme skulle have frembragt et arbejderaristokrati, der ikke mere var tilgængeligt for revolutionære forestillinger og som var medansvarlig for Anden Internationales »forræderi $\ll$.

Sådanne forklaringer refererede endnu til arbejderne $\mathrm{i}$ almenhed eller til privilegerede lag af arbejderklassen, men ikke til den skelnen mellem faglærte, specialarbejder- og ufaglærte fag, der opstår i forbindelse med arbejdsdelingen. Selv om livs- og arbejdsbetingelserne for forskelligt kvalificerede arbejdere var forskellige, så var disse forskelle dog for ringe til at forlede til den antagelse, at rene faginteresser skulle kunne hæmme klassebevidstheden. Tværtimod blev det antaget, at arbejdernes fagforeningsmæssige kampe ville vække og udvikle deres klassebevidsthed. Heller ikke arbejderbevægelsens reformisme refererede til en bestemt faggruppe af arbejdere, men derimod til den alment omsig- gribende illusion, at den arbejdende klasses situation lod sig forbedre progressivt inden for kapitalismen; en illusion, der blev begunstiget af den faktiske udvikling. Først i den seneste tid har man fors $\varnothing \mathrm{gt}$, ikke at forstå forandringerne i arbejderbevægelsen ud fra kapitalens almene udvikling, men ud fra produktionsprocessernes ændrede teknik, der angiveligt har bragt en »anden « end den hidtil kendte arbejderbevægelse med sig.

Roths og Behrens' bog er helliget denne »anden« arbejderbevægelse. Den tese, der fremføres af dem og andre, er meget enkel: Den moderne kapitalistiske teknik gør op med fagarbejderne for at erstatte dem med billigere, ufaglært arbejdskraft, som f.eks. i samlebåndsproduktionen. Disse ufaglærte eller hurtigt tillærte arbejdere er pga. automatiseringen af produktionsprocesserne alment udskiftelige, og kan skitseres under begrebet »totalarbejder « eller »massearbejder «. I modsætning til de uddøende fagarbejdere har »massearbejderne« på ingen måde noget forhold til produktionen; de er totalt »fremmedgjorte « over for arbejdet og ser sig selv som rent vedhæng til maskineriet, der diktatorisk bestemmer deres levemåde. Helt anderledes end de af fagstolthed opfyldte fagarbejdere befinder »massearbejderne«, som følge af deres umenneskeliggjorte stilling i produktionsprocessen, sig i total opposition til det kapitalistiske samfund. Det er »massearbejderne «, der radikalt vil bryde med den gamle arbejderbevægelse, der er bundet til fagarbejdet, for af deres egen situation at skabe sig adækvate aktions- og organisationsformer.

Tesen støtter sig på det strejkeberedskab, der i de seneste år, især i Italien, har været særlig udpræget blandt samlebåndsarbejderne, og på disses bestræbelser på ved hjælp af autonome aktionskomitéer at udvide de $\emptyset$ konomiske kampe ud over de snævre lokale grænser, der foretrækkes af fagforeningerne. Disse bemærkelsesværdige, om end lokale eksempler anses af Roth og Behrens ikke kun for forvarsler for det, der skal komme, men benyttes derimod 
også til at forklare hele den hidtidige arbejderbevægelses svigten ud fra fagarbejdernes formynderskab over den. Også førhen skal det kun have været de ufaglærte eller tillærte arbejdere, som f.eks. mine- og værftsarbejderne, der førte en virkelig klassebevidst kamp mod kapitalen, mens fagarbejderne udgjorde de »bærende søjler« i det reformistiske Socialdemokrati og de klasseforsonende fagforeninger.

Forfatterne kan naturligvis ikke benægte, at fagarbejderne har opbygget deres organisationer i kamp mod kapitalen. Men de fastholder, at denne minoritet inden for den samlede arbejderklasse, på grundlag af dens særlige stilling i produktionen, skulle have forstået at beherske arbejderbevægelsen som helhed. Arbejderklassens revolutionære svigten skulle her have sin væsentligste årsag. Hvad den hidtidige historie har opvist af revolutionære begivenheder skulle helt og holdent være præsteret af »totalarbejderens retsløse parialag «. Om ikke af de nutidige, multinationale samlebåndsarbejdere, så dog af de tillærte arbejdere, der står fremmede over for enhver faglig indbildskhed og hvis kamp hele tiden rettede sig mod mere end den rent fagforeningsmæssige interesse i højere lønninger og bedre arbejdsbetingelser. »Revolutionssoldaterne fra Den røde Ruhrarmé havde «, efter forfatternes opfattelse, »intet til fælles med fagarbejderne, der var fikseret til arbejdets stat (Staat der Arbeit)《, ligesom heller ikke »de ufaglærte arbejderes stødtropper « havde noget at gøre med »fagarbejderavantgardens « begrænsede rådsinitiativer, der kun havde fabriksaut on omien som mål.

Man skulle derfor tale om »to ved siden af hinanden eksisterende strømninger inden for arbejderkampen « nemlig om den arbejderkamp, der føres af den traditionelle arbejderbevægelse, og om en kamp, der foregik og foregår udenfor og imod den officielle arbejderbevægelses begrænsede interesser. Dermed retter kampen mod kapitalen sig samtidig mod den gamle arbejderbevægelse for at gøre den »anden« arbejderbevægelse udslaggivende. Og dette så meget desto mere som den »arbejdsgiverfagforeningsforanstaltede mod offensiv mod massearbejderne « allerede er sat ind gennem en »bevidst iscenesat klassespaltning «. Således er »en næsten hundredårig arbejderkamp-proces efter 1970 afsluttet med det resultat, at den traditionelle arbejderbevægelse uigenkaldeligt og med demonstrativ åbenhed står på den anden side af barrikaden.«

Dette er vel næppe nogen nyhed, selv om det forbliver uforståeligt, hvorledes man, når der ikke er nogen barrikader, kan stå på den anden side af dem. De sidste års klassekampe, de talløse legale og vilde strejker, blev ikke kun gennemført af »massearbejdere «, men derimod af arbejdere fra alle fag, inklusive fagarbejderne, af privat- og statsansatte funktionærer lige til postfunktionærer og politi. Den kendsgerning, at disse kampe forblev under fagforeningsmæssig kontrol eller, hvor de undveg denne, igen førte tilbage til den, har intet at gøre med fagarbejderne eller samlebåndsarbejderne, men med den simple kendsgerning, at det drejede sig om fagforeningsmæssige kampe, ikke om kampe mod det kapitalistiske system selv.

Heller ikke »massearbejderne« har hidtil gennembrudt deres aktioners fagforeningsmæssige karakter; de har, der hvor de har eksisteret i lang tid, dannet industriforbund, der ikke i mindre grad er vokset sammen med det kapitalistiske system end de traditionelle arbejderorganisationer er det. Man behøver blot at tænke på de store industriforbund inden for den amerikanske masseproduktion for straks at indse, at de forventninger, der af Roth og Behrens knyttes til »massearbejderne«, er præcist lige så illusionistiske som de, der i sin tid var knyttet til fagarbejderne. Men Roth og Behrens forventer mere, nemlig opløsningen og $\varnothing$ delæggelsen af den samlede arbejderbevægelse, som den hidtil er blevet forstået, og udviklingen af »helt nye kampformer«, med hvilke den uorganiserede eller, over for arbejderorganisationen, oprørske »massearbejder« gør sig gældende. 
Om disse »nye kampformer « siges ganske vist inderligt lidt, og det, der siges, som f.eks. om fabriksbesættelserne som strejkemiddel, refererer ikke kun til »massearbejderne«, men til de mest forskelligartede arbejderkategoriers aktioner. Derudover bliver der kun henvist til former for arbejderkamp under fascistiske betingelser, der fremstår som nægtelse af krævede ydelser, pjækkeri og skjult sabotage. Man fors $\varnothing-$ ger at fremkalde det indtryk, at arbejderne under alle omstændigheder, og uden at officielle arbejderorganisationer lægger sig imellem, ikke blot yder modstand, men fører deres kamp mere effektivet end det var muligt under den gamle fagforeningskontrol. Således kaster Roth og Behrens sig ud i den vanvittige påstand, at naziregimet, som følge af de arbejderkampe, der blev ført under det, blev trængt ud i en reel krise, der kun kunne overvindes gennem udløsningen af krigen. Lynkrigen opfattes af dem som et »instrument til nysammensætning af arbejderklassen«, for via indstættelse af udenlandske tvangsarbejdere at knække de tyske arbejderes revolutionære vilje. På denne måde forvrænges kendsgerninger med vold og mod al logik til ukendelighed for at tilpasse dem den forudfattede tese. Der er næsten ingen af de eftervisninger, der bringes af dem, der ikke viser sig at være forfalskede interpretationer af de medtagne fakta. Og i de tilfælde, hvor eftervisningerne ikke stammer fra dem, henfører de til de propagandistiske falskmeldinger fra eksilbureaukratiet i den afgåede arbejderbevægelse, der fungerede i Paris, Prag eller Basel.

Er bogen selv et ulideligt makværk, så er det problem, som den berører, dog af største vigtighed for arbejderklassen. At den traditionelle arbejderbevægelse ikke blev til den revolutionære bevægelse har siden 1914 været klart for enhver. Men at den eksisterer videre i stadig mere reaktionære former kan dog ikke føres tilbage til fagarbejdernes beherskelse af den, men derimod til kapitalens uventede magtudfoldelse og styrke. Ude af stand til at gennemføre re- volutionen fors $\emptyset$ gte arbejderne at indrette sig så godt som muligt inden for kapitalismen. Til dette formål var den traditionelle arbejderbevægelse det egnede instrument, der blev ved med at være virksomt, også da organisationerne gled ud af arbejdernes kontrol og faldt i hænderne på egenmægtige bureaukratier. Det var nu ikke arbejderne selv, men derimod deres »repræsentanter « $\mathrm{i}$ fagforening og parlament og selv i de »revolutionære « partier, der bestemte arbejderbevægelsens teori og praksis og dermed arbejderklassens adfærd. Eftersom denne form for arbejderbevægelse kun kan bestå på de kapitalistiske produktionsforholds grund, blev den naturnødvendigt til en støtte for det kapitalistiske samfund. Dens egen eksistens var bundet til opretholdelsen af kapitalen, selv om den inden for markedsforholdene måtte varetage dens medlemmers interesser for fortsat at kunne bestå som arbejderbevægelse.

I tider, hvor der stilles spørgsmålstegn ved kapitalens eksistens, dvs. i kriser eller revolutionære situationer, stiller de kapitalistisk integrerede arbejderorganisationer sig af simple selvopholdelsesgrunde på kapitalens side. Et socialistiske samfund har hverken plads til partier eller fagforeninger. Men dermed er enhver revolutionær kamp, der sætter sig socialismen som mål, nødvendigvis også en kamp mod de gamle arbejderorganisationer. Kampen drejer sig om den samtidige afskaffelse af markedsog produktionsforholdene, og dermed også om ophævelsen af de forskelle $\mathrm{i}$ arbejderklassen, der er frembragt gennem den kapitalistiske arbejdsdeling.

Men denne kamp står endnu ikke på dagsordenen. I den nuværende krisesituation, som i alle foregående er og bliver det de officielle arbejderorganisationers opgave at hjælpe kapitalen ud af krisen, hvilket kun lader sig gennemføre på arbejdernes bekostning. De repræsenterer således arbejderne, idet de krænker deres umiddelbare interesser. Under sådanne omstændigheder er det mere end sandsynligt, at arbejderne vil gribe til aktionsformer, der er uforene- 
lige med de sædvanlige fagforeningsmæssige metoder, og sætte sig ud over deres egne organisationer, for via mere adækvate organisationer at varetage deres interesser. Og eftersom »massearbejderne «, som Roth og Behrens henholder sig til, er den mest udbyttede gruppe af arbejdere, kan det ligeledes forventes, at de vil være at finde $\mathrm{i}$ spidsen for de kommende klasseopgør.

Det er imidlertid forkert at antage, at klassekampene i den nærmeste fremtid vil stå $i$ »massearbejdernes « tegn. Udviklingen går i anden retning. Arbejdets produktivitet har nået et punkt, hvor antallet af arbejdere, der faktisk er beskæftiget i produktionen, udgør en minoritet af den samlede arbej- derklasse, mens de arbejdere, der er beskæftiget i cirkulationen og andetsteds er blevet til flertallet. Men de arbejdere, der står uden for den direkte produktion, tilh $\varnothing$ rer også arbejderklassen. Den elendigg $\varnothing-$ relse, der er forbundet med krisen, rammer alle arbejdere og tvinger dem til modstand. Klassespaltningen er bestemt af produktionsforholdene, ikke af den skiftende teknik og den heraf bestemte arbejdsdeling. Hvis der findes en fremtid, så tilhører den ikke »massearbejderen«, men arbejderklassen.

Oversat af Kirsten Amstrup og Flemming Olsen

\title{
HUSK AT forny dit abonnement på KURASJE
}

\author{
Nr. 13 - 16: mindst 500 sider for 50,00 kr. \\ Abonnement bestilles ved at indsætte beløbet \\ på giro 7166044 , mærket »13 - 16«.
}

